\title{
Presumptions in EU Competition Law: Blurring the Substantive-Procedural Dichotomy
}

\author{
Xiaowen Tan \\ Shanghai University of International Business and Economics, Shanghai, China \\ Email address: \\ bibleheritage@163.com \\ To cite this article: \\ Xiaowen Tan. Presumptions in EU Competition Law: Blurring the Substantive-Procedural Dichotomy. International Journal of Law and \\ Society. Vol. 4, No. 1, 2021, pp. 1-9. doi: 10.11648/j.ijls.20210401.11
}

Received: December 22, 2020; Accepted: January 5, 2021; Published: January 15, 2021

\begin{abstract}
In EU competition law, presumptions are widely used for reasons of efficiency. However, the legal mechanism for the establishment and application of presumptions in the case law of the Court of Justice of the European Union may not always support efficiency. Instead, the fact that CJEU not only considers the systematic concept of presumptions per se, but also takes into account the full effect of EU law and any directly applicable general legal principles renders the establishment and the application of presumptions unpredictable and sometimes inconsistent. This phenomenon owes largely to the CJEU's contextual approach in interpreting EU law and the fragmentary nature of this approach. To have a better understanding of this phenomenon, this article first explores the operation of presumptions in EU competition law; second, through concrete examples, it examines the Court's approach to establishing and applying the presumptions; third, it identifies the potential impacts of the Court's contextual approach on the enforcement of EU competition law. The article seeks to demonstrate that the Court's interventions in presumption-related issues have blurred the boundary between substantive and procedural law, and thus risk narrowing the principle of national procedural autonomy. The Court's approach also presents challenges for the current system of decentralised enforcement of EU competition law by national courts.
\end{abstract}

Keywords: Presumptions, EU Competition Law, Case Law, Substantive-Procedural Dichotomy

\section{Introduction}

A presumption usually describes an inference from a known fact to an unknown fact. [1] In EU competition law, presumptions are widely employed to prove that an undertaking has engaged in anti-competitive practices.

The justifications for the use of presumptions, as identified by the EU's Directorate-General for Competition, are common sense, effectiveness, the value of experience and the proof proximity principle. [2] Underlying each of these reasons is the fundamental need for procedural efficiency.

The use of presumptions for any reason obviates the need for evidence to establish a proposition. [3] It "conserves [the] resources of competition authorities and the judicial system", [4] leading to a more efficient and less costly judicial process. However, the pursuit of efficiency must not jeopardise the effectiveness of EU competition law, nor breach the general principles of EU law.

To date, academic discussions have focused on the classification of the presumptions adopted by EU competition law, the rationales for their application and the benefits of such presumptions for the enforcement system. However, despite the widespread use of presumptions, the way they are applied by EU courts does not always support the goal of efficiency. Rather, it demonstrates some flaws in the establishment and application of presumptions in the case law of the Court of Justice of the European Union (CJEU).

This article does not seek to review the types of presumptions nor their rationales. Rather, the article's purpose is to examine the way presumptions are applied by the EU's judiciary, and in particular to consider the factors relied upon by the CJEU to establish and apply a presumption - that is, whether the CJEU considers only the systematic concept of presumptions per se or takes into account the full effect of EU law and any directly applicable general legal principles. Next, the article assesses the potential impacts of the Court's approach, both on CJEU case law as a whole and the de-centralised enforcement of EU competition law at large. 


\section{Legal Mechanism of Presumptions}

The Court has developed its approach to presumptions as a part of the overall EU legal system through case law. Two steps are required to transform a presumption from a generic term to a legal term.

First, as noted above, the CJEU presumes certain facts based on repeated occurrence, common sense, policy, procedural convenience, and so on. [5] The result is to classify similar or identical conduct into the same category. It is presumed that all conduct belonging to the same category should be treated equivalently, and that other factors, such as the unique characteristics of the applicant and respondent, may not yield a different result.

To illustrate, a classic example of such a presumption is parental liability. [6] According to this presumption, parent companies are liable for any infringements committed by a wholly-owned or virtually wholly-owned subsidiary, as it is presumed that the parent exercises a decisive influence over the commercial policy of the subsidiary. [7] Other factors, such as whether the parent makes formal management decisions for the subsidiary, [8] whether the parent is aware of the infringement,[6] or whether the parent is a non-operational holding company only conducting financial audits,[9] are irrelevant.

To ascertain one fact based on another is more of a logical process than a legal analysis. The consequence of presuming facts "require [s] the other party to provide an explanation or justification, failing which it is permissible to conclude that the burden of proof has been discharged." [10] Hence, at this stage, presumptions are no more than commonly occurring inferences drawn based on circumstantial evidence. [11] They have no normative consequences beyond the specific cases in which they are applied.

Second, the Court then assesses some presumptions in legal terms. This involves certain legal tests under specific circumstances, where presumptions constitute settled CJEU case law. On rare occasions, such presumptions are irrebuttable and become a rule of per se legality or illegality. [12] Once a legal test is formed, the underlying presumption is endowed with legal validity and its inference is imposed by law. [13]

These legal tests are based on the Court's interpretations of EU law and general EU legal principles. Such interpretations usually focus on the aim and purpose of EU law. [14] For example, the Court requires that to establish a presumption, it must strike a balance between, on the one hand, ensuring the prohibition of anti-competitive behaviours and preventing the repetition of such behaviours and, on the other hand, not vitiating fundamental principles of EU law. These fundamental principles include, among others, the presumption of innocence, the principle of legal certainty and the rights of the defence. [15]

The above example requires a balancing between the full effect of competition law and other legitimate interests. However, the Court has not provided further detail on how this should be achieved. Indeed, it is extremely difficult to codify such a process. Thus far, the Court has only noted that the rebuttable nature of this presumption guaranteed its compatibility with fundamental principles of EU law. [16]

In competition law, the formation of legal tests is a dynamic process. Building on the above example, the balancing exercise has been developed and enriched by CJEU case law, albeit sometimes inconsistently. This inconsistency can be seen, for example, in the CJEU's interpretation on the presumption of innocence.

The establishment of a presumption is often challenged based on the presumption of innocence. [17] This principle is enshrined in art.48(1) of the Charter of Fundamental Rights and constitutes a general principle of EU law. [18] It requires that "no one will be described or treated as guilty of an offence before his guilt has been established by a court". [19]

It is contentious whether the established and legally valid presumptions applied by the CJEU contravene the spirit of EU law by allowing a claimant to assert a proposition, such as the existence of an infringement, with no direct evidence, thus requiring the defendant to prove his innocence. [20] The Court has not been consistent in answering this question.

In E.ON Energies, where there was no direct evidence of concerted practices, the existence of such practices was presumed when it was the only plausible explanation for the observed anti-competitive conduct. [21] The Court then followed the same reasoning in the Polypropylene cartel case, and strongly refuted any conflict between established presumptions and the presumption of innocence. The Court ruled that the application of presumptions neither unduly reversed the burden of proof nor set aside the presumption of innocence. [22] The Court found that the presumption was no more than a standard procedural step; if the Commission was able to establish that an undertaking had taken part in meetings of an anti-competitive nature, that undertaking was then required to provide an alternative explanation of the tenor of those meetings. [22] Although it recognised that this was controversial, the Court saw no conflict between applying presumptions and the principle of the presumption of innocence.

The problem with this ruling is apparent. To say that the application of a presumption is reasonable and legitimate does not justify its compatibility with the general principles of EU law, including the principle of the presumption of innocence. Even if the application of the particular presumption used in the case was compatible with the principle, this does not necessarily indicate that all other established presumptions are compatible.

Later, the Court refined its position and expanded upon its interpretation of the principle of the presumption of innocence. In Eturas, the Court found that an online travel booking company, E-TURAS, had imposed a 3\% cap on its discount rate, which the Competition Council viewed as constituting a concerted practice in violation of art.101(1) of the Treaty on the Functioning of the European Union (TFEU). [17] The referring court presumed that, as parties using the E-TURAS booking system, "the travel agencies were aware, or ought to have been aware", of the message that imposed 3\% cap on 
discount rate at issue in the main proceedings. [17] The Court was called upon to evaluate whether this presumption was compatible with the principle of the presumption of innocence.

The Court started by identifying the presumption of innocence as a general rule of EU law, "which the Member States are required to observe when they implement EU competition law". [17] Next, the Court interpreted the principle from two perspectives: the principle's association with other evidence and the meaning of the right of defence.

First, according to the Court, the principle precluded the referring court from relying solely on the presumption. In other words, the principle requires that a presumption should be read in line with "other objective and consistent indicia". [17] This requires a holistic view of the body of evidence in a particular case to decide whether the application of a presumption is appropriate. To illustrate, in Eturas, the accused agencies, although they did not respond to the collusive message, acted in concert to limit the discount that could be applied to bookings made via the system to $3 \%$ by taking additional technical steps. [17] Thus, it was hard to say that those agencies were not aware of the message, and thus the presumption was not rebutted. Based on this outcome, the interaction of presumptions with other evidence is pivotal.

Second, the Court emphasised the significance of guaranteeing the right of defence, ruling that the principle did not preclude the use of presumptions, insofar as the respondent had a realistic opportunity to rebut them. In Eturas, to rebut the presumption that the accused agencies were aware of the message, the Court considered it sufficient that the agencies could prove that they did not receive the message. [17]

In practice, the respondent rarely provides evidence contrary to a presumption, and the rebuttal of a presumption is often difficult. [2, 15, 23] Even so, a presumption remains within acceptable limits "so long as it is proportionate to the legitimate aim pursued, it is possible to adduce evidence to the contrary and the rights of the defence are safeguarded.' $[15,24]$ The fact that a presumption is difficult to rebut may well illustrate the appropriateness of its application.

\section{The Contextual Approach}

The above discussion of the operation of presumptions generally illustrates the factors required for a presumption to be legally valid, including a consideration of the full effect of EU competition law and other legitimate interests. The Court's approach to establishing and applying presumptions demonstrates some unique features.

\subsection{Presumptions Under Art.101(1) TFEU}

Throughout the years, the Court has established only limited presumptions under art.101(1) TFEU, the most important of which is the rebuttable presumption of cartel participation.

In Montecatini, the General Court (GC) found that Monte had participated in meetings concerning the fixing of price and sales volume targets. Based on previous experience, the Court concurred with the GC's ruling and presumed that Monte "could not [have] fail [ed] to take account, directly or indirectly, of the information obtained during the course of those meetings." [25] Attendance at such meetings was sufficient to prove Monte's participation in the polypropylene cartel. This presumed link is so firmly established in the case law that defences such as failing to take account of a meeting's outcomes or not subscribing to a meeting's intention do not constitute valid counterevidence to rebut the presumption.

This inference removes the need to prove a causal connection between the concerted practices and the market conduct of the undertaking concerned. Similarly, in T-Mobile, where there was concerted action and the undertakings concerned remained active on the market, it was presumed that the undertakings had taken into account the information exchanged with competitors in previous meetings for the purposes of determining their conduct on the market. [26]

In T-Mobile, the issue of presumption was expanded upon further. AG Kokott suggested that the presumption of cartel participation "does not concern the burden of proof or the reversal thereof, but the standard of proof", [4] and is thus governed by national law. However, the CJEU disagreed. Instead, the Court ruled that the presumption of cartel participation stemmed from art.101(1) TFEU, as interpreted by the Court, and it consequently formed an integral part of the applicable EU law. [27] Thus, the presumption is binding on all the national courts and tribunals of Member States when they are applying art.101.

The ruling in T-Mobile grants legal validity to the presumption of cartel participation. Once this presumption applies, subject to proof to the contrary,[10, 26-28] it is for the defendant to prove that either it has "publicly distanced itself from that practice" or it has "reported it to the administrative authorities."[17, 27-29]

To date, this presumption has mostly been applied in cases related to horizontal concerted practices, where proving concerted practices is the priority and such practices can be deduced from some tacit coordination or parallel arrangement. However, a question remains as to whether a presumption which is valid for a particular category of cases can be applied beyond that category.

This extrapolation may not always be possible. In cases of horizontal agreement, the existence of an agreement with an anti-competitive objective is sufficient to establish an infringement of art.101(1) TFEU, and such an anti-competitive objective is easy to find in the text of the agreement. [30]

As to vertical schemes, such a presumption cannot be drawn based on experience. In a complex vertical supply chain, "frequent contacts and strategic coordination are inherent" to such a commercial relationship, [3] and thus can rarely be used as evidence of collusion.

Moreover, when colluding undertakings do not operate on the same level of the supply chain, concerted practices in the upstream market do not necessarily correspond to anti-competitive conduct in the downstream market. [31] 
Unless there is direct evidence indicating the overall plan to collude, the competition authority must show proof of a connection between the concerted practices and the anti-competitive conduct. For instance, in Bayer, the Court ruled that "the mere fact that a measure adopted by a manufacturer, which has the object or effect of restricting competition, falls within the context of continuous business relations between the manufacturer and its wholesalers is not sufficient for a finding that such an agreement exists." [32] Thus, without evidence of tacit participation, such as specific sales conditions, the imposition of service fees on certain sales, or selective distribution, it is extremely difficult to find a vertical arrangement liable for anti-competitive results. [33]

This extrapolation fails because the evidence in competition law cases is largely circumstantial, and thus the relevant court must adopt a contextual approach to deciding whether concerted practices (or cartel participation) can be presumed. Due to the absence of key evidence, which is typically either in the possession of the alleged infringers [28, 34] or hidden, [35] the Court often needs to rely on the body of evidence viewed as a whole. It must draw inferences from a number of "coincidences and indicia" which may, in the absence of plausible alternative explanations, constitute evidence of concerted practices - that is, of the common will of participants. [10, 29, 36] These "coincidences and indicia" must, therefore, be assessed in their overall context. This is a question of evaluation of evidence, "in which the evidential value of various facts is corroborated or weakened by other factors", which, taken as a whole, may show that concerted practices occurred. [37]

In summary, the Court adopts a contextual approach which relies heavily on the evaluation of evidence and takes into account all relevant facts and circumstances, to ascertain whether presumptions can be applied.

It is worth noting that adopting a contextual approach does not prevent the Court from pre-determining several factors when formulating a legal test. The whole process of drawing an inference is presented as a presumption. However, the Court's inquiry into the components of a legal test is far from a broad and generalised analysis. Instead, the Court's consideration of these factors is based on a contextual, circumstantial, fact-intensive and case-specific analysis. Besides, the application of a presumption must be balanced against fundamental EU legal principles to safeguard the individual rights that are derived from EU law, such as the principle of the presumption of innocence. Hence, although presumptions are abstracted from a set of sufficiently similar cases, their establishment and application involve a significant element of substantive law, rather than on procedural rules.

However, there are cases where the extrapolation holds. The "only plausible explanation" presumption is a useful example. According to this presumption, "the existence of an anti-competitive practice or agreement must be inferred from several coincidences and indicia which, taken together, may, in the absence of another plausible explanation, constitute evidence of an infringement of the competition rules.' $[10,36$, 29, 38] This presumption originated in cases related to concerted practices, [39] and has been applied not only to horizontal schemes but also to vertical schemes. [30, 40]

It is not yet clear from the above analysis which established presumptions can be applied to a wider category of cases than others, and why. In extreme cases, presumptions that are codified in the Damage Directive-a secondary EU law-are universally applicable to all infringements of arts 101 and 102 TFEU, and equivalent national competition law. [41]

Unfortunately, there does not appear to be any objective criterion used to delineate presumptions' scope. The application of presumptions seems to be rather random, with some presumptions limited to the type of infringements in which they were established, and some suitable for a wider application.

However, the contextual approach adopted by the Court is unlikely to adequately resolve the question of scope. To emphasise the factual, legal and economic context of a particular case only adds to the complexity of applying an established presumption, and the Court's extremely circumspect approach to balancing between various interests and the fundamental principles of EU law further complicates matters. These ambiguities raise the issue of whether presumptions are truly achieving their goal of providing legal certainty to companies operating in the EU.

\subsection{Restriction of Competition "by Object" as a Presumption}

Among the various presumptions under art.101(1) TFEU, the mystery of "by object" infringements has confounded courts, competition authorities and legal scholars for years. In this article, the significance of discussing this category of infringements is that the notion of restriction "by object" is, in essence, a presumption. [2, 42]

According to the Court, certain types of coordination between undertakings are, by their very nature, harmful to the proper functioning of competition. [26] These include, for instance, horizontal agreements that lead to price-fixing, market-sharing and output-limiting. [43] These types of coordination usually lead to decreases in production output, reduced price increases, and poor allocation of resources. They are detrimental, in particular, to consumers. [42] Thus, based on experience, the Court presumes that such coordination, once proved, violates EU competition law, regardless of any actual or potential effect.

However, ambiguity remains as to the objective criterion that the Court uses to determine whether a practice or agreement is restrictive by object under EU competition law. In the language of presumptions, it is unclear which factors are required to satisfy the relevant legal test and categorise an agreement into the category of restriction "by object". The factors which would unable an undertaking to rebut this presumption are also uncertain.

Recent CJEU case law has significantly clarified these issues by interpreting the constituent elements of a "by object" infringement. In Generics, the Court held that an agreement amounted to restriction by object when it did not have any 
plausible explanation other than the restriction of competition. [40] This definition is consistent with a contextual approach, in which the object of an agreement or concerted practice is examined on a case-by-case basis.

In line with this contextual approach, in Cartes Bancaires, the Court held that to find a by object infringement within the meaning of art.101(1), regard must be had to (i) the content of the collusive coordination, (ii) its objectives, and (iii) the economic and legal context in which it occurred. [42] The Court further clarified that when determining the economic and legal context, it is necessary to consider "the nature of the goods or services affected, as well as the real conditions of the functioning and structure of the market or markets in question." $[42,44]$ These three factors constitute the legal test for restriction by object. When these three factors cumulatively reveal "a sufficient degree of harm to competition", it can be presumed that the coordination in question involved a restriction of competition by object. Other factors, such as the parties' intentions or any pro-competitive effects of the coordination, may contribute to the finding, but are not in themselves decisive. [42]

A contextual approach that incorporates a comprehensive factual, economic and legal analysis based on the facts of a particular case is unlikely to achieve the legal certainty intended by the establishment of presumptions. This presumption is indeed not "straight forward to implement in practice". [6] As a result, it is unsurprising that EU courts have found that seemingly clear by object infringements do not necessarily breach art.101(1) under the specific circumstances of each case. Likewise, conduct that appears to comply with competition law may, nevertheless, be found to have an anti-competitive object. [44]

As to the rebuttal of this presumption, in Budapest Bank, the Court held that the defendant provided strong indications of a contradictory or ambivalent element - that is, a pro-competitive effect, such evidence cannot be ignored by the court in deciding whether there was a restriction "by object". [45] Such effects should be "not only demonstrated and relevant but also specifically related to the agreement concerned."'[40] Thus, rebuttal of the presumption requires an equally substantial counter-argument.

It follows that evidence of pro-competitive effects may be drawn from the content of the coordination [42] or its economic and legal context. [46] This means, in essence, that the rules governing the burden of proof are in practice truly relevant only where both parties provide sound, conclusive arguments and reach different conclusions.

In light of the demanding criteria for establishing an anti-competitive object, the extent to which this presumption streamlines the procedure in relevant cases is questionable. Admittedly, this presumption does relieve competition authorities (or claimants) of the need to conduct a complex and time-consuming assessment of market impacts,[47] but goes no further than that. The entire process of developing an inference, from analysing the facts to reaching the conclusion (i.e. the finding of a restriction by object), is unavoidable, although it may take less time than the procedure for finding a restriction by effect. [48]

The purpose of developing the effect and object dichotomy is, thus, unclear, given that demonstrating both restriction by object and restriction by effect requires an in-depth case-specific analysis. It may be more straightforward to say that restriction of competition is the key, and to simply regard restriction by object as a category of collusive conduct to which a legal presumption of an anti-competitive effect on the market applies.

\subsection{Presumptions Under Art.102 TFEU}

Compared with the limited examples under art.101, the Court has employed presumptions more widely under art.102, in almost all the elements that are necessary to prove a breach of the article, from dominance to abuse.

Save in exceptional circumstances, dominance is presumed when a firm holds a very large share of the relevant market. [49] This presumption was re-affirmed in Akzo in relation to an undertaking with a market share of over 50\%. [50] Market share is an important indicator of market power - that is, that an undertaking holds a dominant position in the market. Such a presumption incorporates insights from mainstream economic theory and practical experience, avoiding the need for burdensome economic analysis. [51]

However, market share merely provides a useful indication of market structure and the importance of various undertakings in the market. [52] The commercial behaviour of a dominant undertaking may not always distort competition. Nevertheless, presumed dominance indicates that the undertaking concerned has a special responsibility "not to allow its behaviour to impair genuine, undistorted competition on the internal market." [53]

In light of this special responsibility, the Court applies presumptions to establish an abuse of dominance. In Hoffmann-La Roche, the Court established that exclusivity and fidelity rebates that bound customers to the exclusive provision of supplies or granted financial advantage were presumptively abusive. [54] The Court reasoned that such rebates, if granted by a dominant company, would "deprive the purchaser of or restrict his possible choices of sources of supply and... deny other producers access to the market."[49] When engaged in by a dominant firm, this type of conduct is, by nature, capable of restricting competition.

In Intel, the Court illuminated three ways to rebut this presumption. [53] The dominant undertaking can adduce sufficient evidence to either objectively justify the conduct, show there has been no exclusionary effect, or demonstrate efficiency gains that are sufficient to compensate for the foreclosure effects. [55] In either case, defence of the presumption requires a contextual rebuttal based on a case-specific analysis. [56]

\subsection{The Fragmentary Nature of the Contextual Approach}

As noted in the introduction, presumptions are expected to contribute to the clarity of competition rules, foster predictability and legal certainty, and thus enable the effective 
enforcement of competition law. [6, 57] This might be true for individual legally valid presumptions; the overall picture, however, is quite the opposite.

As discussed above, the Court adopts a contextual approach to the establishment and application of presumptions. By requiring a thorough examination of all relevant factual, legal and economic factors, the Court demonstrates that its use of presumptions is reasonable and legitimate, prevents conflicts of interest, and ensures that EU laws and general legal principles are respected.

The nature of such a contextual approach means that few presumptions are universally applicable. Some presumptions are interpretations of EU competition law and are granted legal validity, whereas others are not. The only way to distinguish between the types is to identify whether the CJEU has explicitly stated that a particular presumption constitutes an interpretation of arts 101 and 102 TFEU or an integral part of those articles.

However, the Court does not grant legal validity to a presumption in a single instance. The establishment of presumptions is based on experience; only when an inference appears frequently in cases will the Court apply the contextual approach and decide that a presumption should be binding.

However, there does not appear to be an objective criterion for deciding when a presumption should be established. This decision seems to depend entirely on the Court considering that there is sufficient proof of previous experience and it is appropriate to establish a presumption. This practice leads to the co-existence of both binding and non-binding presumptions.

This distinction has further implications. If some presumptions are established in CJEU case law, questions relating to the application of these presumptions are a question of EU law. Hence, they must be applied uniformly among Member States, without national deviations or divergences. On the other hand, non-binding presumptions fall within national jurisdictions. As a result, national statutes and case law apply, leading to variations between Member States. [58] Thus, from a holistic point of view, the fragmentary nature of presumptions does not grant sufficient legal certainty.

Even when certain presumptions are established with legal validity, difficulties may arise in their application. For presumptions established in CJEU case law, the Court cannot identify an exhaustive list of situations in which such presumptions may apply. Hence, the application of presumptions is always open to interpretation, which may lead to the creation of exceptions and rebuttals, or even the modification of established presumptions. [2]

This is also true for presumptions which are codified in EU law. For example, art.17 of the Damage Directive presumes that cartels cause harm. The presumption of harm relies on the lesson of experience that more than nine out of ten cartels cause illegal overcharges. [59] It presumes a causal link between the cartel and an effect on price.

National variations appeared when this article was transposed into national law. For example, some countries appended an additional presumption of overcharge to the presumption of harm,[60] while some extended this presumption beyond cartel cases. [61] Even when the original wording was transposed exactly, the notions of "harm" and "cartel" may still vary among Member States.

In any event, national courts, in applying this presumption, need to consider each of its elements. Having regarded all the facts and circumstances before them, national courts need to identify the harm caused by the infringement, the party which suffered the harm, and where the harm occurred. Otherwise, a robotic application of the presumption may lead to over-compensation in cases where a collusive scheme did not result in any damage or where cartels were planned but not implemented. [62]

Then again, the contextual approach applies. National courts' application of such presumptions must incorporate the assessment of evidence and application of the standard of proof, the result of which is governed by national law under the principle of procedural autonomy and is subject to the principles of equivalence and effectiveness. [17] EU legislators have "consciously accepted the existence of certain variations in Member State practice." [4] According to AG Kokott, such variations are inherent in the decentralised enforcement of EU competition law. [4]

\section{Blurring the Substantive-procedural Dichotomy}

The contextual approach strikes a balance between conflicting interests and guarantees the full effect of EU law and general EU legal principles. Because of this, the result of the contextual approach cannot be criticised. However, the Court's overwhelming emphasis on contextual analysis, as well as the required balancing among all legitimate interests, may blur the boundary between substantive and procedural law.

The establishment and application of presumptions are elements of substantive EU law, as they embody a contextual analysis and are tightly connected to the evaluation of evidence and the standard of proof. However, the result of applying a presumption is to shift the burden of proof, a purely procedural operation.

This generates some problems, as presumptions are, ultimately, a burden-shifting mechanism. The Court thus engages in de facto regulation of the burden of proof through a contextual analysis of case-specific facts and circumstances. Oddly, procedural law consequences are determined by substantive law analyses. Presumptions, therefore, neither guarantee legal certainty and procedural convenience (as procedural law should), nor do they define rights and responsibilities (as substantive law should).

Legal scholars have attempted to characterise presumptions as pre-determined rules, according to the "proof-proximity principle". [3, 63] Under this principle, the use of presumptions does no more than allocate the burden of proof to the party which is more likely to hold the relevant evidence. [3] However, the identification of the party which has better access to the evidence must consider the economic and factual 
context, the result of which should be balanced against various legal principles. Thus, presumptions cannot be characterised as pre-determined rules.

In addition, the issue of the scope of presumptions is becoming increasingly significant. As the Court randomly harmonises questions or segments of national procedure,[64] the growing body of CJEU case law, which de facto regulates the burden of proof, is encroaching upon national civil procedure and, thus, risks narrowing the principle of national procedural autonomy. [65]

In this context, the Court's role in developing EU law is critical. When applying presumptions, the Court deviates from its traditional approach of intervening only when national courts request preliminary rulings from the Court to obtain authoritative interpretations of genuine ambiguities in EU law. Instead, the Court establishes and applies presumptions in any appropriate and necessary case.

The case law demonstrates the Court's tendency to develop a set of binding rules that establish presumptions and regulate the application and rebuttal of these presumptions. This law-making process goes beyond the original role of the CJEU, which is to give effect to the sometimes imprecise, incomplete or excessively general provisions of EU law, and to enable the law to remain contemporary. [66]

Besides, these rulings are context-specific and policy-oriented. They do not deal with the conventionally systematic concept of presumptions per se, but rather with the effects of Treaty provisions and the directly applicable EU legal principles. Hence, they do not only generate procedural efficiency; instead, their function is to implement competition policies and safeguard the uniform application of EU law. As a result, these rulings are fragmentary, non-systemised and sometimes internally inconsistent. [67]

Therefore, it is questionable whether national courts will embrace the Court's contextual approach to adjudicating presumptions, given that this is a procedural law issue and falls within national procedural autonomy. Adopting the Court's contextual approach would confine the allocation of the burden of proof to context- and effect-based value assessments only, which are to be decided by national courts based on national civil procedural law.

\section{Challenges in the Enforcement of EU Competition Law}

The legal operation of presumptions in competition law brings into question the traditional dichotomy between substantive and procedural law. It is problematic when the Court's substantive law analyses have procedural law consequences.

This observation is not limited to the issue of presumptions. For example, the Commission has also introduced the balancing test to the disclosure of evidence in private enforcement of EU competition law. [68] Notably, both presumptions and disclosure of evidence are evidence-related issues.

These circumstances present challenges for the de-centralised enforcement of EU competition law before national courts, requiring the parallel application of both EU law and national law to presumption-related issues in competition law cases. National courts are obliged to treat presumptions differently in cases concerning the application of EU competition law or equivalent national competition rules, as compared to other civil cases.

Such a parallel application imposes high demands on the quality and capacity of national judiciaries in dealing with competition law cases. For these national courts, the issue of presumptions is determined not by pre-determined evidentiary rules, but by a contextual evaluation that takes into account all relevant facts and circumstances, and that complies with all EU law and general EU legal principles.

In developing the case law on presumptions and other competition law-specific issues, the CJEU risks reinforcing the image of EU competition law as highly specialised, "inaccessible to the outside world", and unable to be fully integrated into the basic "tool kit" of ordinary judges. [69] National courts may choose to avoid problematic contextual evaluations by ignoring competition law issues and failing to consider relevant EU law.

If this occurs, the Court's efforts to safeguard the full effect of EU law and EU legal principles is doomed to futility, because it will come at the expense of fewer references to EU law by national courts. Thus, the Court's approach likely does not support the "harmonisation" that the de-centralised enforcement system for EU competition law is intended to achieve. [70]

\section{Conclusion}

In EU competition law, presumptions are established and applied far beyond the function to obviate the need for evidence to establish a proposition. The Court's contextual approach imposes a substantive requirement to evaluate not only EU law principles but also facts and circumstances of a particular case in order to decide the establishment and the application of presumptions. As a result, presumptions are no longer simply a procedural law tool to shift the burden of proof, but also a substantive law element to ascertain a fact or to attribute to a certain extent legal liabilities. Hence, it blurs the subtantive-procedural dichotomy and, thus, renders the consequent application of presumptions unpredictable and inconsistent. This is one of the challenges imposed by the de-centralised enforcement system, and will continue to be one as the Court expands its balancing exercise in interpreting the EU law, including EU competition law.

\section{References}

[1] Bruzzone, G. and Boccaccio, M. (2009). "Impact-based Assessment and Use of Legal Presumptions in EC Competition Law: The Search for the Proper Mix". World Competition, 32, 465; Heydon, D. (2013). Cross on Evidence, 9th edn, LexisNexis Butterworths, p. 299; Castillo de la Torre, F. and Gippini-Fournier, E. (2017). Evidence, Proof and Judicial Review in EU Competition Law, Edward Elgar, p. 58. 
[2] Ritter, C. (2018). "Presumptions in EU Competition Law". Journal of Antitrust Enforcement, 6 (2), 189-191. For an earlier attempt at classification, see Bailey, D. (2010). "Presumptions in EU Competition Law”. E. C. L. R. 31, 362.

[3] Volpin, C. (2014). "The Ball is in Your Court: Evidential Burden of Proof and the Proof-proximity Principle in EU Competition Law". C. M. L. Rev. 51 (4), 1159-1164. See also Decker, C. (2009). Economics and the Enforcement of European Competition Law, Edward Elgar, pp. 193-194.

[4] T-Mobile (C-8/08) EU: C: 2009: 110, Opinion of AG Kokott.

[5] Emson, R. (2008). Evidence, 4th edn, Palgrave Macmillan, p. 407.

[6] Akzo Nobel (C-97/08 P) EU: C: 2009: 536; [2009] 5 C. M. L. R. 23 at - .

[7] A "virtually wholly-owned subsidiary" refers to the situation where a parent company owns $99 \%$ or $98 \%$ of a subsidiary and exercises a decisive influence. Arkema (C-520/09 P) EU: C: 2011: 619 .

[8] Portielje (C-440/11 P) EU: C: 2013: 514.

[9] Edison (T-196/06) EU: T: 2011: 281.

[10] Aalborg Portland (C-204/00, C-205/00, C-211/00, C-213/00, C-217/00 and C-219/00) EU: C: 2004: 6.

[11] Griffiths, J., McKeown, P. and McPeake, R. (2012). Evidence, 16 th edn, OUP, p. 36.

[12] Expedia (C-226/11) EU: C: 2012: 79.

[13] Duff, R. (2005). "Strict Liability, Legal Presumptions, and the Presumption of Innocence" in Simester, A. (ed), Appraising Strict Liability, OUP, p. 130.

[14] Arnull, A. (2006). The European Union and Its Court of Justice, 2nd edn, OUP, p. 612. See also Schilling, T. (2010). "Beyond Multilingualism: On Different Approaches to the Handling of Diverging Language Versions of a Community Law". European Law Journal 16 (1), 47-60.

[15] Elf Aquitaine (C-521/09 P) EU: C: 2011: 620.

[16] Leddy, M. and Van Melkebeke, A. (2019). "Parental Liability in EU Competition Law”. E. C. L. R., 40 (9), 407-410.

[17] Eturas (C-74/14) EU: C: 2016: 42.

[18] Charter of Fundamental Rights [2016] OJ C 202/389.

[19] Franchet and Byk (T-48/05) EU: T: 2008: 257.

[20] To that effect, see, e.g. Blanco, L. (2006). European Community Competition Procedure, 2nd edn, OUP, p. 162; Lenaerts, K. (2007). "Some Thoughts on Evidence and Procedure in European Community Competition Law". Fordham International Law Journal, 30 (5), 1463-1471.

[21] Capobianco, A. (2011). "OECD Roundtable on Safe Harbours and Legal Presumptions in Competition Law". 128th Meeting of the OECD Competition Committee, Paris, para 11.

[22] E.ON Energies (C-89/11 P) EU: C: 2012: 738.

[23] For example, the presumption of parental liability has only been rebutted four times to date. See Air Liquide (T-185/06) EU: T: 2011: 275.
[24] Spector Photo Group and Van Raemdonck (C-45/08) EU: C: 2009: 806.

[25] Montecatini (C-235/92 P) EU: C: 1999: 362.

[26] T-Mobile (C-8/08) EU: C: 2009: 343.

[27] Hüls (C-199/92 P) EU: C: 1999: 358.

[28] Anic Partecipazioni (C-49/92 P) EU: C: 1999: 356.

[29] Total Marketing Services (C-634/13 P) EU: C: 2015: 614.

[30] See e.g. Technische Unie (C-113/04 P) EU: C: 2006: 593 - exclusive dealing agreements.

[31] See relevant factors for assessment of vertical agreements under art.101(1) in, Commission, "Commission Notice Guidelines on Vertical Restraints" [2010] OJ C 130/1, paras 111-121.

[32] Bayer (C-2/01 P and C-3/01 P) EU: C: 2004: 2.

[33] For other legal presumptions applying to vertical restraints, see Commission Regulation (EU) No 330/2010 of 20 April 2010 on the application of Article 101 (3) of the Treaty on the Functioning of the European Union to categories of vertical agreements and concerted practices [2010] OJ L102/1.

[34] Enichem Anic (T-6/89) EU: T: 1991: 74.

[35] Coats Holdings (T-439/07) EU: T: 2012: 320. The infringers held clandestine meetings in different countries, most frequently in a non-member country. The associated documents were reduced to a minimum.

[36] Verhuizingen Coppens (C-441/11 P) EU: C: 2012: 778.

[37] BPB (T-53/03) EU: T: 2008: 254.

[38] Villeroy \& Boch Austria GmbH (C-626/13 P) EU: C: 2017: 54.

[39] Wood Pulp (C-89/85), EU: C: 1993: 120.

[40] Generics (C-307/18) EU: C: 2020: 52.

[41] Directive 2014/104/EU on certain rules governing actions for damages under national law for infringements of the competition law provisions of the Member States and of the European Union [2014] OJ L 349/1 ("Damage Directive"), art.2.

[42] Cartes Bancaires (C-67/13 P) EU: C: 2014: 2204.

[43] BIDS (C-209/07) EU: C: 2008: 643.

[44] Allianz Hungária Biztosító (C-32/11) EU: C: 2013: 160.

[45] Budapest Bank (C-228/18) EU: C: 2020: 265.

[46] Murphy (C-403/08 and C-429/08) EU: C: 2011: 631.

[47] Zelger, B. (2017). “'By Object' Restrictions Pursuant to Article 101 (1) TFEU: A Clear Matter or a Mess, and a Critical Analysis of the Court's Judgement in Expedia?". European Competition Journal, 13 (2-3), 356.

[48] This is dissimilar to the position of per se infringements under Section 1 of the Sherman Act. Ibáñez Colomo, P. and Lamadrid, A. (2017). "On the Notion of Restriction of Competition: What We Know and What We Don't Know We Know" in Gerard, D., Merola, M. and Meyring, B. (eds), The Notion of Restriction of Competition: Revisiting the Foundations of Antitrust Enforcement in Europe, Bruylant. 
[49] Hoffmann-La Roche (C-85/76) EU: C: 1979: 36.

[50] Akzo Chemie (C-62/86) EU: C: 1991: 286.

[51] Lowe, P. (2006). "Remarks on Unilateral Conduct", Federal Trade Commission and Antitrust Division Hearings on Section 2 of the Sherman Act, Washington D.C.

[52] Guidance on the Commission's enforcement priorities in applying article 82 of the EC Treaty to abusive exclusionary conduct by dominant undertakings [2009] OJ C45/7, para 13.

[53] Intel (C-413/14 P) EU: C: 2017: 632.

[54] Tetra Pak (C-333/94 P) EU: C: 1996: 436.

[55] Fernández, C. (2009). "Presumptions and Burden of Proof in EU Competition Law: The Intel Judgment". Journal of European Competition Law \& Practice, 10 (7), 448.

[56] Communication from the Commission-Guidance on the Commission's Enforcement Priorities in Applying Article 82 of the EC Treaty to Abusive Exclusionary Conduct by Dominant Undertakings (Guidance Paper) (2009) OJ C 45/7, paras 28-31.

[57] General Qu1'mica (C-90/09 P) EU: C: 2010: 517.

[58] Skanska Industrial Solutions (C-724/17) EU: C: 2019: 204.

[59] Oxera and others, (2009). "Quantifying Antitrust Damages Towards Non-Binding Guidance for Courts". Study prepared for the European Commission, < https://op.europa.eu/en/publication-detail/-/publication/fc6673 87-4658-48de-aa44-0f9b0dd3327d/language-en>, p. 91, accessed 23 June 2020. As quoted by Practical Guide, 93\% of the cartel cases in the sample resulted in overcharges. Commission, "Commission Staff Working Document Practical Guide on Quantifying Harm in Actions for damages based on breaches of Article 101 or 102 of the Treaty on the Functioning of the European Union", SWD (2013) 205, ("Practical Guide").
[60] Filippeli, M. (2020). "Presumption of Harm in Cartel Damages Cases". E. C. L. R. 41 (3), 137-140.

[61] Malinauskaite, J. and Cauffman, C. (2018). “The Transposition of the Damages Directive in the Small Member States of the EU - A Comparative Perspective". Journal of Competition Law \& Practice, 498.

[62] Odudu, O. and Sanchez-Graells, A. (2017). "The Interface of EU and National Tort Law", in Giliker, P. (ed), Research Handbook on EU Tort Law. Edward Elgar, p. 164.

[63] Faull, J. and Nikpay, A. (eds), (2007). The EC Law of Competition, 2nd edn OUP, pp. 94-95.

[64] Bobek, M. (2014). "The Effects of EU Law in the National Legal Systems", in Barnard, C. and Peers, S. (eds), European Union Law, OUP, p. 165.

[65] See the principle of national procedural autonomy in Rewe (C-33/76) EU: C: 1976: 188.

[66] EU Parliament, (2017). "The EU as a Community of Law: Overview of the Role of Law in the Union", Briefing, $<$ https://www.europarl.europa.eu/RegData/etudes/BRIE/2017/ 599364/EPRS_BRI(2017)599364_EN.pdf>, p. 7, accessed 18 June 2020.

[67] Weatherill, S. (2011). "Interpretation of the Directives: The Role of the Court", in Hartkamp, A., Hesselink, M., Hondius, E., Mak, C. and du Perron, E. (eds), Towards a European Civil Code, Wolters Kluwer, p. 185.

[68] Damage Directive, art.5. See also Donau Chemie (C-536/11) EU: C: 2013: 366.

[69] Prechal, S. (2006) "National Courts in EU Judicial Structure". Yearbook of European Law, 25 (1), 429-436.

[70] von Bogdandy, A. (2010) "Founding Principles of EU Law". Revus, 12, para 41. 